\title{
Auditing Subsequent Events from the Perspective of Auditors: Study from Jordan
}

\author{
Musa Abdel Latif Al Nawaiseh ${ }^{1} \&$ Jamel Jaber ${ }^{1}$ \\ ${ }^{1}$ The University of Jordan, Amman, Jordan \\ Correspondence: Dr. Musa Abdel Latif Al Nawaiseh, The University of Jordan, Amman, Jordan. E-mail: \\ m.nawayseh@ju.edu.jo
}

Received: March 30, 2015

Accepted: June 16, 2015

Online Published: July 6, 2015

doi:10.5430/ijfr.v6n3p78

URL: http://dx.doi.org/10.5430/ijfr.v6n3p78

\begin{abstract}
The study aims to identify to what extent auditors in Jordan comply with the requirements of the International Standard of Auditing No. 560, "Subsequent Events."

The Researcher in the study used the descriptive approach and the analytical approach, through a questionnaire developed for the same purpose, and aims to answer the questions of the study, and to test hypotheses depending on a sample of (62) auditors working in auditing offices, they were selected randomly . The sample represents (32.8\%) of the study population that consists of (189) auditing offices.

The study shows that the auditors in Jordan comply with the requirements of the auditing standard No. (560) in auditing subsequent events in the period between the balance sheet date and the date of auditing report. They did not comply with the requirements of this standard after that date. The study shows also that the personal characteristics of the auditors (speciality, experience, CPA exams, and training) did not have statistically significant effects on their awareness of the importance of compliance with the requirements of this standard.

The study recommends offices and auditing firms and the Association of Auditors to take care of training their auditors and employ only members who pass the CPA exam.
\end{abstract}

Keywords: event, materiality, balance sheet date, auditor's report date, issuing financial statements date

\section{Introduction}

Reviewing the comparative financial statements of some companies showed that there were some changes in the balances of some items. The causes of that may be the emergence of the events that have material effects in the financial statements, bad classification of accounts in these statements, ignoring the requirements IAS (1) or the requirements of IAS (10). This problem may be acceptable to some companies' managements, but what the role of the auditor in such cases' is, and whether he takes in his account the international standard of Auditing (560), which required giving an opinion about the fairness of the data presented in the statements of the client. This phenomenon was repeated in many of the comparative statements of the same company that I have seen, the adjustments due to misclassification were continued in occurrence in spite of the existence of internal, and the external auditing.

This study aimed to know to what extent the auditor's comply with the requirements of the ISA 560 "Subsequent Events".

\section{The Problem of the Study}

In spite of practicing the auditing process by auditors, the statements of some companies are still showing different data in their comparative statements from year to year. This means that there were events occurred after the date of preparation of the auditor's report, and managements didn't tell the auditor about events or there was no disclosure about them, or the auditor did not take care of these events after the issuance of reports. The study aims to answer the following questions:

Q1: Is the auditor committed to the requirements of the ISA 560 in the treatment of subsequent events occurring after the balance sheet date and before the issuance of the auditing report?

Q2: Is the auditor committed to the requirements of the ISA 560 in the treatment of subsequent events, which lies between the issuance of the audit report and the issuance of the financial statements? 
Q3: Do the demographic characteristics of the auditors (speciality, experience, examinations, training) have affected their awareness of the importance of complying with the requirements of ISA 560 ?

\section{The Objectives of the Study and Its Importance}

The study aims to identify the extent of the auditors' commitment to the requirements of ISA (560) in auditing the subsequent events. The importance of the study comes from that it is the first one in Jordan that tests the auditors' commitment by the requirements of this standard.

\section{Hypotheses}

H1: auditors don't comply with the requirements of the ISA 560 in auditing subsequent events in the period between the balance sheet date and the issuance of the auditor's report date.

H2: auditors don't comply with the requirements of ISA 560 in auditing the subsequent events in the period between the issuance of the auditor's report date and the issuance of the financial statements date.

H3: The demographic characteristics of the auditors (specialty, experience, CPA exams, and training) didn't have a statistically significant effect in their awareness of the importance of applying ISA 560.

\section{The Theoretical Framework and Previous Studies}

Subsequent events are events that occur between the date of the financial statements and the date of ratification and issuance of these statements (IAS 10.3,10, AUS 706 and SFAS 165) they are the events that have material effects on the items of the financial statements, they provide evidence of the conditions that have been showed until the end of the period financial report (IAS 10.3, Al-Shammari, et al., 2007). The events that do not require modification of the financial statements' items are those that fall after the financial reporting period, and should be disclosed because they will affect the ability of users of these statements to take appropriate decisions (ISA 560, Botez, 2014). Disclosure must contain the nature of the event and the estimate of the effect on financial data (IAS $10.19 \& 21$, SFFAS 39, Abu Nassar, and Gomaa, 2015). Events that do not affect the financial statements, directly or indirectly, don't need disclosure in the financial statements if they would cause damage to the facility and policies of the company (Abdullah 2010).

The company should disclose the responsible who delegates authority to mend and issue the financial statements after they are released (IAS 10.17, Ameriic et al., 2004, Glaum and Street 2003).

There are few studies conducted on the effects of subsequent events on financial data. One of these studies developed a model to show the various factors that influence the effectiveness of auditing subsequent events; these factors include environmental factors, the personal characteristics of auditors and the audit function. This model provides a theoretical basis that can be relied upon in future studies which will deal with the reasons for the gaps and deficits and suggested possible strategies that can be used by auditors to improve the effectiveness of auditing subsequent events. Researchers found that a third of the checking process that have been done in PCAOB and releases issued by the SEC identify gaps in auditing of the previous events (Chung et al., 2013, Carmichael 2004). SEC report has recently requested reducing the period between the balance sheet date and the final financial report date to reduce subsequent operations that need treatments by manager or the auditor.

The professional groups CICA and AICPA are afraid of the low availability of evidence for subsequent events, because this will lower the quality of financial reporting and will affect the auditor's judgment. Another study examined how auditors looking for subsequent events, discovering the evidence, and the factors affecting the process (Janvrin and Jeffrey 2007, CICA 2004), researchers found from analyzing auditors' responses in four large companies and a national company that auditors comply with auditing standards, and the disclosure of the adjustments resulting from the subsequent events which are important to users of financial statements (Michel 2015).

The auditor is responsible for taking appropriate action on identifying the events that occur between the date of preparing financial statements and the date of his report, identifying the extent of materiality, and make sure of the updating of accounts through developing an audit plan, following the proper procedures to enable him to obtain assurances on these treatments and getting enough evidence on these treatments, and obtain assurances of borderline. In order to achieve this, he would do the followings (Bec 2009, AUS 7061955 Tamimi 2004, Ritterberg et al., 2012):

- Tracing the company procedures of subsequent events, and ask management to tell him, who is responsible for preparing financial statements.

- Reading the minutes of meetings of the board and the competent committees that help him in completing the auditing of subsequent events. 
- Inquiring management about contingent liabilities, changes in capital, and changes in accounting estimates.

- Inquiring management about the state of subsequent events.

- Inquiring any other auditors about the subsidiaries' procedures and treatments of subsequent events.

Auditors are not responsible for any events occurring after issuing their reports until the date of approving and issuing the financial statements. Company's management is responsible for these events; it must inform the auditor for the state of these events. In this case, it must amend the financial statements by the effect of these events, and the auditor should take the appropriate action by expanding the fieldwork period. If management doesn't respond to the auditor's request to amend financial statements, he can change his opinion if he hasn't give management his report, but if he has sent his report to the management, he must recommend the management not to publish financial statements and if the management has not implemented his request, he can tell users to stop depending on his report. (Schipper 2007; Gomaa 2009)

Also, the auditor doesn't responsible for the subsequent events that have a material effect on the financial data after the publication of the company's financial statements, but he can discuss that with the management, if it amended the data he must notify users about the new situation, and provide the management with a new report including a confirmation paragraph after the opinion paragraph in his report, and he should released the new report prior to the ratification of the revised financial statements. But if managements didn't amend the financial statements or did not inform all users who show the previous data before the amendment, in this case he can take appropriate procedures to prevent using these data. If the preparation of financial statements for the new period become soon he must make sure that the new data include disclosure of that fact (Thunaibat 2015).

\section{The Study Methodology}

The study is based on a descriptive approach, where the survey was conducted for preceding related studies. The study also depended on analytical methods, through a questionnaire that was developed for the same purpose to answer the study's questions, and test hypotheses.

\subsection{The Population and the Sample of the Study}

The study population consisted of all auditors registered in (189) auditing offices in Jordan. The study depends on a sample of (40\%) of these offices, the researcher sent (76) questionnaires to these offices and collected (68) of them. The valid questionnaires for the purposes of the study were (62), which represents $32.8 \%$ of the distributed questionnaires.

\subsection{Study Tool}

After reviewing the previous studies that conducted on auditing subsequent event, for the purposes of collecting data which will help to test hypotheses of the study, a questionnaire has been developed. It contains two parts, the first part includes paragraphs measuring the personal characteristics (speciality, experience, CPA exams, and training) of the auditors, and Part two consists of (18) phrases that measure the variables of the study, phrases (1-12) measure the first hypothesis, phrases (13-18) measure the second hypothesis.

In the study Likert scale is used to determine the weights of the phrases of the questionnaire, they are as follow: (Strongly Disagree, was given one degrees), (disagree was given two degrees), (neutral, was given three degrees), (agree, was given four degrees), (strongly agree, was given five degree). See appendix (1).

\subsection{Validity and Reliability of the Questionnaire}

The questionnaire is sent to (3) arbitrators of accounting professors in Jordanian universities, and modified at their recommends, the stability of the questionnaire was tested depending on the Cronbach's alpha scale, and found that the reliability coefficient $(0.859)$.

\subsection{Statistical Methods}

In this study the statistical methods that used to test the hypotheses were: descriptive statistics measurements depending on the statistical package (SPSS) to describe the study sample characteristics, and One Sample T - test to compare the averages calculated with the central premise of the steps of the scale applied in this study, and ANOVA Test to identify statistically the significance of the perceptions of auditors of the importance of applying ISA 560 requirements that can be attributed to demographic variables (speciality, experience, examinations, training) 


\section{Results and Analysis}

\subsection{The Characteristics of the Study Population}

Table 1 shows that $69.4 \%$ of the auditors has B.A in accounting, this means that a large proportion of them is aware of what he is doing as an accountant and as an auditor, $60 \%$ of them his experience more than ten years, although this did not affect their application the requirements of the ISA 560 after the issuance of the auditor's report, and 58.1\% of them had an audit license from his previous job (auditor in the Audit Bureau or estimator in the income tax, and got the courses during work).

Table 1. Demographic characteristics of the auditors

\begin{tabular}{lll}
\hline Characteristic & Frequency & Percentage \\
\hline Speciality & & \\
\hline Accounting & 43 & $69.4 \%$ \\
\hline Others & 19 & $30.6 \%$ \\
\hline Experience & 7 & $11.3 \%$ \\
\hline Less than five years & 7 & $29.0 \%$ \\
\hline From 6 to 10 years & 18 & $38.7 \%$ \\
\hline From 11 to 15 years & 24 & $21.0 \%$ \\
\hline More than 15 years & 13 & \\
\hline Professional exams & & $37.1 \%$ \\
\hline JCPA & 23 & $4.8 \%$ \\
\hline CPA & 3 & $58.1 \%$ \\
\hline Nothing & 36 & \\
\hline Professional training & & $67.7 \%$ \\
\hline In auditing & 42 & $32.3 \%$ \\
\hline Nothing & 20 &
\end{tabular}

\subsection{Answer the Questions of the Study}

The following is the analysis of the study's questions

First question: Is the auditor committed with the requirements of the ISA 560 in the treatment of subsequent events occurring after the balance sheet date and before the issuance of the auditing report?

The means and standard deviations for auditors' responses are calculated on the phrases of the questionnaire (1-12), which measure this question, and the results came out as in Table 2, which indicates that the arithmetic average for all phrases (3.419), is greater than the score of the tool (3), and that the average was positive and statistically significant at a confidence level (0.05), this means that auditors committed with the ISA 560 requirements.

Table 2. One-sample T-Test statistics

\begin{tabular}{lccccc}
\hline pharses & Average & Std & T & fd & Sig. \\
\hline P 1 & 3.29 & 1.030 & 2.218 & 61 & 0.030 \\
P2 & 3.73 & 0.872 & 6.557 & 61 & 0.000 \\
P3 & 3.40 & 1.078 & 2.945 & 61 & 0.005 \\
P4 & 3.73 & 1.104 & 5.177 & 61 & 0.000 \\
P5 & 4.00 & 0.768 & 10.25 & 61 & 0.000 \\
P6 & 3.37 & 1.090 & 2.680 & 61 & 0.009 \\
P7 & 3.27 & 1.257 & 1.718 & 61 & 0.091 \\
P8 & 3.81 & 0.786 & 8.08 & 61 & 0.000 \\
P9 & 3.82 & 0.915 & 7.080 & 61 & 0.000 \\
P10 & 3.61 & 1.030 & 4.686 & 61 & 0.000 \\
P11 & 3.82 & 0.984 & 6.583 & 61 & 0.000 \\
P12 & 3.56 & 1.096 & 4.057 & 61 & 0.000 \\
\hline General Average & 3.419 & 0.869 & 3.798 & 61 & 0.000 \\
\hline
\end{tabular}


Table 2 also indicates that the largest averages are the averages yield to phrases No. 9 and No. 1, this means that the auditors focused on asking managements about lawsuits, and on reading the minutes of meetings and reports of committees because they provide them with information about the important issues.

Second question: Is the auditor committed to the requirements of the ISA 560 in the treatment of subsequent events, which are between the issuance of the audit report and the issuance of the financial statements?

The arithmetic average and standard deviations for auditors answers are calculated on the phrases that measure the audit procedures in the period between the audit report date and the date of issuance of the financial statements, and measured by phrases (13-18), and show the analysis of results as in Table 3 that the arithmetic average for all the phrases are (2.782), which is less than the score of the tool (3), and that the average is positive and statistically significant at a confidence level (0.05). This means that the auditors didn't comply with the requirements of IAS 560 relating to audit subsequent events after the issuance of the auditor's report.

Table 3. Statistics One-sample Test

\begin{tabular}{lccccc}
\hline Phrases & Average & Std & T & F.D & Sig \\
\hline P 13 & 2.890 & 1.404 & 0.633 & 61 & 0.829 \\
P 14 & 3.160 & 1.357 & 0.936 & 61 & 0.035 \\
P 15 & 2.850 & 1.377 & 0.830 & 61 & 0.410 \\
P 16 & 3.060 & 1.436 & 0.354 & 61 & 0.825 \\
P 17 & 2.890 & 1.368 & 0.650 & 61 & 0.518 \\
P 18 & 2.680 & 1.556 & 1.633 & 61 & 0.108 \\
\hline General Average & 2.782 & 1.348 & 1.272 & 61 & 0.208 \\
\hline
\end{tabular}

Table 3 also indicates that the largest averages are the averages yield to phrases (14) and (17). This means that the auditors didn't inquire about the events subsequent to the issuance of the audit report.

The third question: Do the demographic characteristics of the auditors (speciality, experience, examinations, training) have an effect on their awareness of the importance of complying with the requirements of ISA 560.

Table 4 shows that the values of calculated $\mathrm{F}$ for variables speciality, experience and professional exams are lower than the tabular values of them and therefore the variables did not have a statistically significant impact at a confidence (0.05) on their awareness of the importance of complying with the requirements of the ISA 560, and the only variable that left such an impact is the training courses in audit.

Table 4. One way - ANOVA

\begin{tabular}{rcccccc}
\hline Variables & S.S & M.S & fd & Calculated F & Tabulated F & Sig \\
\hline Speciality & 0.037 & 0.037 & $(1,60)$ & 0.043 & 4,000 & 0.837 \\
Experience & 0.752 & 0.254 & $(3,58)$ & 0.274 & 2.768 & 0.814 \\
Professional exams & 0.755 & 0.378 & $(2,59)$ & 0.415 & 3.234 & 0.662 \\
Training & 6.912 & 6.912 & $(1,60)$ & 8.718 & 4.000 & 0.004 \\
\hline
\end{tabular}

\subsection{Test Hypotheses}

H 1: the auditor does not comply with the requirements of the ISA 560 in the treatment of subsequent events in the period between the balance sheet date and the date of issuance of the audit report?

Table 2 shows that the calculated value of $t$ (3.798) at the confidence level (0.05), and this value is greater than tabulate value (1.669) when the degrees of freedom (61), so that this hypothesis is rejected, This means that the auditors comply with the requirements of ISA 560 on auditing subsequent events in the period between the balance sheet date and the date of issuance of the auditor's report.

H 2: the auditor does not comply with the requirements of the ISA 560 in the treatment of subsequent events in the period between the issuance of the audit report and the issuance of the financial report. 
Table 3 shows that the absolute calculated value was $(-1.272)$ at a confidence level $(0.05)$, and this value is less than tabulated value (1.669) when the degrees of freedom (61), depending on One test -Sample T test, the hypothesis is accepted, and this means that the auditors do not comply with the requirements of this standard on auditing events after the date of issuance of the auditor's report.

H 3: the demographic characteristics of the auditors (speciality, experience, examinations, and training courses) do not affect in their awareness of the importance of complying with the requirements of the ISA No. 560, "Subsequent Events.

Table 4 shows that the values of calculated $\mathrm{F}$ of the variables speciality, experience and professional exams are lower than the tabular values tabular if it and therefore the variables did not have a statistically significance impact at a confidence (0.05) on their awareness of the importance of complying with the requirements of the ISA 560.

\section{Conclusion}

From the above we can conclude that auditors comply with the requirements of the ISA 560 for subsequent events that occur between the balance sheet date and the date of the auditor's report, this result agree with the results of the study of Chung et al., (2013)and Carmichael (2004) or the results of PCAOB. Also we can conclude that auditors don't comply with the requirements of this standard for these events that occur after the auditing report date. And the personal characteristics of the auditors don't have a statistically significant impact on their awareness of the importance of commitment with the requirements of this standard.

\section{Recommendations}

The study recommends the offices, audit firms and the Association of Auditors to train their members in applying IFRSs and ISAs, to employ only the auditors who pass CPA exams.

It also recommends the companies to benefit from the preceding studies in the same area, to reduce the period between the balance sheet date and the issuing the financial report to reduce the appearance of new transaction, and the unusual subsequent events, and to disclose the events that occur after the date of issuing the final financial report.

\section{References}

\section{In English}

Al-Shammari, B., Brown, P., \& Tarca, A. (2007). An Investigation of Compliance with International Accounting Standards by Listed Companies in the Gulf Co-Operation Council Member States. Working paper, University of Western Australia.

American Institute of Certified Public Accountants (AICPA). (2004). AICPA Professional Standards. New York NY: AICPA.

Ameriic, J., Borwen, J., \& Wiecek, I. (2004). Subsequent Events. Canadian Academic Accounting Association (CAAA). Retrieved from https://www.caaa.ca/Archive/Practice/ExpsrDrftCom/ASED/events.html

AUS 706 "Subsequent Events". (1995). Australian Accounting Research Foundation.

Bec, N.R. (2009). To what extent are disclosures of subsequent events adopted by Private Equity companies?. Master Thesis, Faculty of Economics and Econometrics, Universteit Van Amesterdam. p.42

Botez, D. (2014). Subsequent Events and their Importance in Drawing up Annual Financial Statements. Retrieved from http://sceco.ub.ro/index.php/SCECO/article/view/241

Canadian Institute of Chartered Accountants. (2004). Accounting Standards Board Proposed Accounting Recommendations, Subsequent Events. Toronto, Ontario: CICA.

Carmichael, D.R. (2004, June). The PCAOB and the social responsibility of the independent auditor. Accounting Horizons, 18, 127-134.

Chung, Junne O.Y, et al. (2013). The Auditor's Approach to Subsequent Events: Insights from the Academic Literature. Auditing: A Journal of Practice \& Theory, 32(supplement 1), 167-207. http://dx.doi.org/10.2308/ajpt-50328

Glaum, M., \& Street, D.L. (2003). Compliance with the Disclosure requirements of Germany's New Market: IASs Versus US GAAPs. Journal of International Financial Management \& Accounting, 14(1), 64-70.

IAS 10. Events after the Reporting Periods. Retrieved from http://www.iasplus.com/en/standards/ias/ias 10

ISA 560. Subsequent events. Retrieved from http://pakaccountants.com/standards/isa/isa560/3 
Janvrin, D.J., \& Jeffrey, C.G. (2007). An Investigation of Auditor perceptions about Subsequent Events and Factors That Influence This Audit Task. Accounting Horizons, 21(3), 295-312. http://dx.doi.org/10.2308/acch.2007.21.3,295

Michel, J. (2015). Disclosures versus Recognition: Inferences from Subsequent Events. http://dox.doi.org/10.2139/ssrn.2324394

Ritterberg, L.E., Johnstone, K., \& Gramling, A. (2012). Auditing: A Business Risk Approach (8 ${ }^{\text {th }}$ ed.). Retrieved from http://books.google.jo/books

Schipper, K. (2007). Required disclosures in financial reports. The Accounting Review, 82(2), 301- 326.

Securities Exchange Commission (SEC). (2002). SEC to propose new corporate disclosure rules. Retrieved from http://www.sec.gov/news/headlines/corpdiscrules.htm

SFAS 165 "Subsequent Events". FASB Issues. (2009). Retrieved from http://www.fasb/cs

SFFAS 39 "Subsequent Events". (2010). Federal Accounting Standard Advisory Board (FASAB). Retrieved from http://www.fasab.gov

\section{In Arabic}

Abdullah, K.A. (2010). Aware of the audit: theory and practical ( $5^{\text {th }}$ ed.). Dar Wael for publication.

Abu Nassar, M., \& Gomaa, H. (2015). The international accounting standards and financial reporting: Theoretical and practical aspects $\left(2^{\text {nd }}\right.$ ed.). The Jordanian university publications.

Gomaa, A.H. (2009). The entrance to the Auditing and Assurance talk: international context ... the evidence and the results of the audit ( $1^{\text {st }}$ ed.). Serenity House for Publishing and Distribution, Oman, p. 440.

Tamimi, H. (2004). The Entrance to the audit of the theory and practical $\left(2^{\text {nd }}\right.$ ed.). Dar Wael for publication.

Thunaibat, A.A-Q. (2015). The Accounting audit in light of international standards: theory and application (5 $5^{\text {th }}$ ed.). Dar Wael.

Appendix 1.

Questionnaire

Dear

Best greeting

Please fill the questionnaire, the data will be treated secretly.

Part one: Demographic characteristics

Put (x) on the suitable choice

Speciality

$\begin{array}{ll}\text { (1)Accounting } & \text { (2) others }\end{array}$

Experience
(1)Less than 5 years
(3) from 11 to 15 years
(2) From 5 to 10 years
(4) more than 15 years

Professional exams

(1)JCPA

(3) Another exam

(2) CPA

Professional Training

(1) Get in training program in auditing

(2) Don't get in training program in auditing. 
Part Two: please put $(\mathrm{x})$ on the suitable choice for you

\begin{tabular}{|c|c|c|c|}
\hline \multirow{2}{*}{\multicolumn{4}{|c|}{$\begin{array}{l}\text { Phrases } \\
\text { P 1. We ask management for any subsequent events that require issuing } \\
\text { new opinion or judgment from the auditor. }\end{array}$}} \\
\hline & & & \\
\hline \multicolumn{4}{|l|}{$\begin{array}{l}\text { P } 2 . \text { We ask management for any subsequent events that require proceeded } \\
\text { raw data. }\end{array}$} \\
\hline \multicolumn{4}{|l|}{ P 3. We ask management for any commitments or guarantees. } \\
\hline \multicolumn{4}{|l|}{$\begin{array}{l}\text { P 4-We ask management for any sales, or any adjustments to asset after } \\
\text { the balance sheet date. }\end{array}$} \\
\hline \multicolumn{4}{|l|}{$\begin{array}{l}\text { P 5. We ask management for any modifications to the capital structure } \\
\text { after the balance sheet date. }\end{array}$} \\
\hline \multicolumn{4}{|l|}{$\begin{array}{l}\text { P 6. We ask management if there have been developments included } \\
\text { hazardous areas or the presence of contingent liabilities after the } \\
\text { balance sheet date. }\end{array}$} \\
\hline \multicolumn{4}{|l|}{$\begin{array}{l}\text { P 7. We ask management for unusual favorable adjustments occurred after } \\
\text { the balance sheet date. }\end{array}$} \\
\hline \multicolumn{4}{|l|}{$\begin{array}{l}\text { P } 8 \text {. We ask management for any conditions affecting the imposition of } \\
\text { continuity occurred after the balance sheet date. }\end{array}$} \\
\hline \multicolumn{4}{|l|}{$\begin{array}{l}\text { P 9. We ask management about any consequent rights or obligations } \\
\text { occurred after the balance sheet date. }\end{array}$} \\
\hline \multicolumn{4}{|l|}{ P 10. We examine if the management identifies subsequent events. } \\
\hline \multicolumn{4}{|l|}{$\begin{array}{l}\text { P 11. We read the minutes of the meetings of the Board of directors, } \\
\text { landlords and councils, committees and the reports about the } \\
\text { extraordinary items. }\end{array}$} \\
\hline \multicolumn{4}{|l|}{$\begin{array}{l}\text { P 12. We get a written explanation from the management for the } \\
\text { subsequent events and the need to adjust the financial statements or } \\
\text { disclosure in these lists. }\end{array}$} \\
\hline \multicolumn{4}{|l|}{$\begin{array}{l}\text { P 13. Management informs us with any subsequent events that have a } \\
\text { material effect on the financial data. }\end{array}$} \\
\hline \multicolumn{4}{|l|}{$\begin{array}{l}\text { P 14. We do not do anything for subsequent events after the issuance of } \\
\text { the auditing report. }\end{array}$} \\
\hline \multicolumn{4}{|l|}{$\begin{array}{l}\text { P 15. If we know that subsequent events have an impact on the financial } \\
\text { data and they occurred after the audit report date, we discuss that with } \\
\text { the management and determine whether they need amendments to the } \\
\text { financial data and the report }\end{array}$} \\
\hline \multicolumn{4}{|l|}{$\begin{array}{l}\text { P 16. If we found that the amendments to the financial statement as a } \\
\text { result of subsequent events occurred after the issuance of audit report } \\
\text { are necessary and management didn't do that, and we didn't give it the } \\
\text { auditing report, we should adjust our opinion. }\end{array}$} \\
\hline \multicolumn{4}{|l|}{$\begin{array}{l}\text { P 17. If we found that the amendments to the financial statements as a } \\
\text { result the events occurred after the issuance of the auditing report are } \\
\text { necessary, and we gave the report to it and it didn't do that, then we } \\
\text { should Ask management not to issue the financial statements. }\end{array}$} \\
\hline $\begin{array}{l}\text { P 18. If we found that the amendments to the financial statements as a } \\
\text { result the events occurred after the issuance of the audit report are } \\
\text { necessary, but the management didn't do that, and the financial and the } \\
\text { financial Statements issued, we should take all procedures to prevent } \\
\text { reliance on the auditing report. }\end{array}$ & & & \\
\hline
\end{tabular}

Note: (1) indicates to strongly disagree, (2) to disagree, (3) to neutral, (4) to agree, (5) to strongly agree. 